\title{
THE ASSESSMENT OF RISK ZONES IN `TOPČIDER`PARK FOREST ON THE BASIS OF THE HEALTH CONDITION OF WOODY PLANT SPECIES
}

\author{
Katarina MLADENOVIĆ $C^{l}$, Zlatan RADULOVIĆ $C^{l}$,Vlado ČOKEŠA ${ }^{l}$, \\ Đorđe JOVIĆ ${ }^{1}$, Ivan MILENKOVIĆ
}

\begin{abstract}
This paper provides the assessment of the zones of risk for the users of Topčider Forest Park. The assessment was done according to the health condition of woody plant species as determined in 2017, the position of roads, footpaths and parking lots, the age of trees etc. In order to establish the priorities in terms of monitoring and rehabilitation measures within the forest park, four risk zones were distinguished: a very high-risk zone, a high-risk zone, a medium-risk zone and a low-risk zone. The criterion for the identification of trees that pose a potential threat to all forest users (local population, picnickers, recreational athletes, etc.) was the health condition of the leaf mass, branches, trunks, as well as biotic and abiotic damage.
\end{abstract}

Key words: risk zones, assessment of health condition, woody plant species, Topčider Forest Park

\section{PROCENA RIZIČNIH ZONA PARK ŠUME TOPČIDER NA OSNOVU ZDRAVSTVENE KONDICIJE DRVENASTIH BILJNIH VRSTA}

Izvod: U radu je data procena rizičnih zona za korisnike park šume Topčider na osnovu zdravstvenog stanja drvenastih biljnih vrsta utvrđenog u 2017. godini, pozicije saobraćajnica, pešačkih staza, parkovskog mobilijara, starosti stabala itd. Kako bi se utvrdio prioritet nadzora i mera sanacije unutar park šume izdvojene su četiri zone rizika:

\footnotetext{
${ }^{1}$ dr Katarina Mladenović, dr Zlatan Radulović, mr Vlado Čokeša, dr Djordje Jović, Institute of Forestry, Kneza Višeslava 3, Belgrade, Serbia

${ }^{2}$ dr Ivan Milenković, Phytophthora Research Centre, Faculty of Forestry and Wood Technology, Mendel University, Brno, Czech Republic

Corresponding author: Katarina Mladenović, e-mail: katarina.mladenovic@gmail.com
} 
zona vrlo visokog rizika, zona visokog rizika, zona srednjeg rizika i zona malog rizika. Preduslov za evidentiranje stabala koji mogu predstavljati potencijalnu opasnost za sve korisnike šuma (stanovništvo, izletnike, rekreativce itd.) je bilo utvrđivanje trenutne ocene zdravstvenog stanja na osnovu kondicije lisne mase, grana, debla, biotičkih $i$ abiotičkih oštećenja.

Ključne reči: zone rizika, ocena zdravstvenog stanja, drvenaste biljne vrste, park šuma Topčider

\section{INTRODUCTION}

As a monument of nature, the protected area 'Topčider' Forest Park is classified into protection category III - a protected area of local significance (Nature Protection Act, Official Gazette RS, No. 36/09, 88/10, 91/10). Restrictions within the established protection regime do not apply to the activities of maintaining the forest area which are in line with the relevant management plan or to the introduction of new species of trees and shrubs which are according to their biological properties suitable for the environmental conditions and whose properties and aesthetic characteristics match with this area of natural and cultural heritage. They neither apply to the technical measures for the protection against plant pathogens and entomological damage or to the tending measures and removal of woody specimens that do not meet the health, aesthetic and functional criteria of the protected area or the justified replacement of one species with another. According to the Forest Management Plan, this forest park belongs to 'Topčider' Forest Management Unit, compartment 3a, which includes a part of the Topčiderska River alluvial plain and belongs to the zone of thermophilic Hungarian oak - Turkey oak forests: Quercion frainetto (Stevanović, et al., 1995) or the forests of pedunculate oak and hornbeam: Carpino-Quercetum roboris (Gajić, 1952).

Topčider Forest Park has a great historical, aesthetic and recreational value. It is part of the urban system of green areas and at the same time, it is a link between the city and the countryside. The forest park of 'Topčider' Protected Area is very sensitive from the aspect of nature and the environment as it is in the center of intensive urban road infrastructure and together with surrounding forests modifies the climate of the city by increasing the humidity and reducing air pollution. After this autochthonous forest had changed its purpose in the mid $20^{\text {th }}$ century, its environmental conditions were altered significantly due to the activities that this change entailed such as concrete reinforcement of the Topčider River channel, introduction of numerous allochthonous species, increased human pressure, etc. This altered environment reduced the physiological fitness of woody plant species which made them more susceptible to adverse effects of numerous biotic and abiotic factors. Apart from mechanical injuries, changes can also be caused by the harmful effects of numerous pathogens and pests whose toxic effect can be detected on plant organs. Individual and combined effects of man, pathogens and pests result in defoliation, discolouration, reduced ornamental value and decreasing vitality which in the long run lead to the dieback, uprooting, etc. 
and pose a potential threat to forest users. The synergistic and/or simultaneous attack of harmful insects and pathogenic fungi leads to the growth reduction, shoot and branch die-back, increased canopy transparency, and crown decline (Agrios 2005; Karadžić 2010; Mihajlović 2008).

\section{MATERIAL AND METHODS}

In order to determine the zones of risk for Topčider Forest Park users, field investigations were carried out four times during the growing season of 2017.

In order to establish the priorities in terms of monitoring and rehabilitation measures for the trees that pose risk to public safety, four risk zones were distinguished:

- Very high-risk zone - red - close to the roads, playgrounds, restaurants, tram station, most frequent footpaths, parking lots, complete die-back of some trees (grade 1).

- High-risk zone - orange - less frequent footpaths, trees affected the die-back processes (grades 2 and 3 ).

- Medium-risk zone - yellow - less frequently used sites in the forest park, trees whose health conditioin requires monitoring (grade 3 ).

- Low-risk zone - green - areas of the forest park with small or limited access, healthy trees or trees with minor injuries (grades 4 and 5).

The following criteria were used to distinguish the risk zones: the proximity to roads (tram tracks, tram stop, footpaths, and parking lots), the available facilities (restaurants, shops, etc.), the frequency of the forest park use, and the health condition of the forest park trees (phytopathological, entomological, acarological, and mechanical damage) and the age of the trees.

The inspection of the health condition included the detection of mechanical, phytopathological, entomological and acarological damage to the tree crown, trunk and root collar zone, as well as biotic and abiotic damage determination. The current health condition was assessed and the factors that potentially threaten it were identified using a visual assessment with the following 1 to 5 scale: 1 - a dead tree; 2 - a dying tree with a reduced leaf area and advanced trunk and branch decay which poses a risk to public safety; 3 - a tree with considerable damage, having evident foliar injuries and damaged trunk and branches, dry-topped, decayed trunk and/or branches, requires rehabilitation measures; 4 - a tree with minor injuries, spot damage to the leaf mass, trunk and branches, a small percentage of rotten branches; 5 - a healthy tree with no or few symptoms of leaf mass, trunk and branch damage (Mladenović et al., 2016). Young trees were excluded from the assessment.

The inspection included the following plant species: Acer campestre L., A. dasycarpum Ehrh., A. negundo L., A. pseudoplatanus L., Aesculus hippocastanum L., Alnus glutinosa Gaer., Betula alba L., Carpinus betulus L., Cornus mas L., Crataegus monogyna Jacq., Fagus moesiaca (Domin, Maly) Czeczott., Fraxinus excelsior L., F. ornus L., Gleditsia triacanthos L., Juglans regia L., Picea abies 
Kalrst., Pinus nigra Arg., P. strobus L., Pirus communis L., Platanus acerifolia (Ait.) Willd., Populus alba L., P. nigra L., Prunus cerasifera Ehrh., Quercus cerris L., Q, robur L., Robinia pseudoacacia L., Salix alba L., Samubcus nigra L., Syringa vulgaris L., Tilia argentea Desf., T. cordata Mill, T. grandifolia Enhr., Ulmus carpinifolia Gled., U. effusa Willd..

The plant material required to determine the plant diseases and pests occurring in order to assess their significance and contribution to the die-back process was collected by the random selection method or on the basis of the symptoms present in the forest. Harmful organisms were identified by the microscopic method at the entomological and phytopathological laboratory of the Institute of Forestry. The samples had been packed in polyethylene bags and stored in the refrigerator at a temperature of $5^{\circ} \mathrm{C}$ before they were used for the identification at the laboratory of the Institute of Forestry. Identification of phytopathogenic organisms was done using the light microscope and in pure cultures after the isolation according to numerous different keys: Agrios (2005); Alexopoulos et al., (1996); Barnett and Hunter (1998); Breitenbach and Kränzlin (1986); Černy (1989); Davidson et al., (1938); Gilbertson (1979); Hagara et al., (2012); Jung (2009); Jung et al., (1996, 2000); Karadžić (2010); Karadžić et al., (2014); Karadžić and Milenković (2014, 2015); Milenković 2015); Murrill (1903, 1908); Overholts (1953); Pegler and Waterston (1968); Ryvarden and Johansen (1980); Stalpers (1978); Wagner and Fischer (2002). In order to identify pests, insects and mites, the following taxonomic literature and keys were used: Amrine et al., 2003; Baker et al., 1996; Domes 1998; Keifer 1938-1979; Malandraki et al., 2004; Nalepa 1910; Petanović 1988a, b; Shi \& Boczek 2000; Baker \& Tuttle 1994; Mitrofanov et al., 1987; Migeon and Dorkeld (2018); Prichard \& Baker, 1955; Reeves, 1963; Rota, 1962; SmithMeyer 1987; Begljarov 1981; Chant 1959; De Moraes et al., 1986, 2004; Demite et al., 2018; Karg 1993; Alford 1995; Johnson \& Lyon 1991; Maceljski 1986, 2002; Mihajlović 2007, 2008; Petrović-Obradović 2003; Tanasijević and Simova-Tošić 1987; Strous \& Winter 2000).

\section{RESEARCH RESULTS AND DISCUSSION}

Most of the observed trees in Topčider Park Forest were found to be in the group of trees with small to considerable damage. The critical trees which were planned to be removed were scored 1 or 2 , while there were some critical trees designated as trees for further monitoring that were scored 3. It could be also observed that the vitality of individual trees of certain species varied greatly depending on the position in the stand. The assessment of the health status of trees depending on their position in Topčider Forest Park is given in Table 1. 
Table 1: Average assessment of the health status of trees in Topčider Forest Park

\begin{tabular}{|l|c|c|}
\hline Woody plant species & $\begin{array}{c}\text { Assessment scores of the } \\
\text { trees in the busy part of } \\
\text { the park }\end{array}$ & $\begin{array}{c}\text { Assessment scores of the } \\
\text { trees in the interior of the } \\
\text { forest park }\end{array}$ \\
\hline Acer campestre & 3,5 & 4,8 \\
\hline Acer dasycarpum & 2,0 & 3,0 \\
\hline Acer negundo & 2.2 & 3.9 \\
\hline Acer pseudoplatanus & 4.0 & 4.2 \\
\hline Aesculus hippocastanum & 2.4 & 3.9 \\
\hline Alnus glutinosa & 4.5 & 4.9 \\
\hline Betula alba & 4.1 & 4.9 \\
\hline Carpinus betulus & 3.8 & 4.2 \\
\hline Crataegus monogyna & 4.4 & 5.0 \\
\hline Fagus moesiaca & 3.5 & 4.4 \\
\hline Fraxinus excelsior & 3.7 & 4.3 \\
\hline Fraxinus ornus & 3.3 & 4.5 \\
\hline Gleditsia triacanthos & 2.6 & 4.0 \\
\hline Juglans regia & 4.0 & 4.0 \\
\hline Picea abies & 3.5 & 4.7 \\
\hline Pinus nigra & 2.5 & 4.5 \\
\hline Pirus communis & 4.0 & 4.0 \\
\hline Platanus acerifolia & 4.0 & 4.0 \\
\hline Populus alba & 2.5 & 3.3 \\
\hline Prunus cerasifera & 4.8 & 5.0 \\
\hline Quercus cerris & 4.0 & 4.6 \\
\hline Quercus robur & 3.5 & 4.3 \\
\hline Robinia pseudoacacia & 4.3 & 4.9 \\
\hline Salix alba & 4.0 & 4.4 \\
\hline Tilia argentea & 3.8 & 4.2 \\
\hline Tilia cordata & 3.8 & 4.3 \\
\hline Tilia grandifolia & 3.9 & 4.1 \\
\hline Ulmus carpinifolia & 2.0 & 2.6 \\
\hline average & $\mathbf{3 . 5}$ & $\mathbf{4 . 2}$ \\
\hline
\end{tabular}

It was observed that the most threatened trees of Topčider Park Forest were close to footpaths, parking lots, tram tracks, park furniture, etc, and their average score of the health status amounted to 3.5. The negative human effects were particularly visible in the busy part of the Park Forest, while the trees in the interior stands had much better health status, which was confirmed by the higher score of the health status of 4.2. The following tree species showed the greatest difference in the obtained scores depending on their position in the forest park: A. campestre, A. dasycarpum, A. negundo, A. hippocastanum, $F$. ornus, $G$. triacanthos, $P$. abies and $P$. nigra. The differences in the health condition of the investigated woody species between the trees in the interior stands and the sites with the high frequency of population was the result of numerous, minor or major mechanical injuries which made entrance holes for pathogenic organisms agents of tree decay that consequently endangered the safety of the forest park users. The most common pathogens were the agents of white and central rot, root decay, leaf spots, mildew, etc. The damage caused by parasitic fungi was found to be far greater than the damage caused by the detected insects and mites.

The following tree species had the most favourable health and physiological condition in Topčider Park Forest: A. campestre, A. glutinosa, B. alba, Prunus spp., Q. cerris, R. pseudoacacia, S. alba and C. monogyna. The following species proved to be less resistant to biotic and abiotic damage: $A$. 
dasycarpum, A. negundo, A. hippocastanum, G. triacanthos, $P$. nigra, $P$. alba i $U$. carpinifolia (Mladenović et al., 2018). Autochthonous species of pedunculate oak, narrow-leafed ash, field elm, alder, white elm, willow, etc. should be more common in the park forest in the future. Overmature trees of $P$. alba, P. communis, A. negundo etc., and the trees of poor health condition, such as A. dasycarpum, $A$. negundo, A. hippocastanum, G. triacanthos, P. nigra, P. alba and U. carpinifolia, should be gradually removed from the stands to avoid the preventive measures of reducing the risk of branch breakages or uprooting of entire trees and thus ensure the public safety. Allochthonous species of A. dasycarpum, A. negundo, G. triacanthos with poor health status should be replaced with autochthonous species. The abundance of locust, as invasive species, needs to be reduced.

The risk zones distinguished in Topčider Forest Park are shown in Figure 1.

The red zone is the zone of very high risk in the immediate vicinity of the tram tracks and the tram stop, the most frequent footpaths, restaurants and parking lots. The high-risk orange zone is close to less frequent footpaths, the mid-risk yellow zone is part of the forest park that is less frequently visited by the public while the green zone as a low-risk zone has restricted public access.

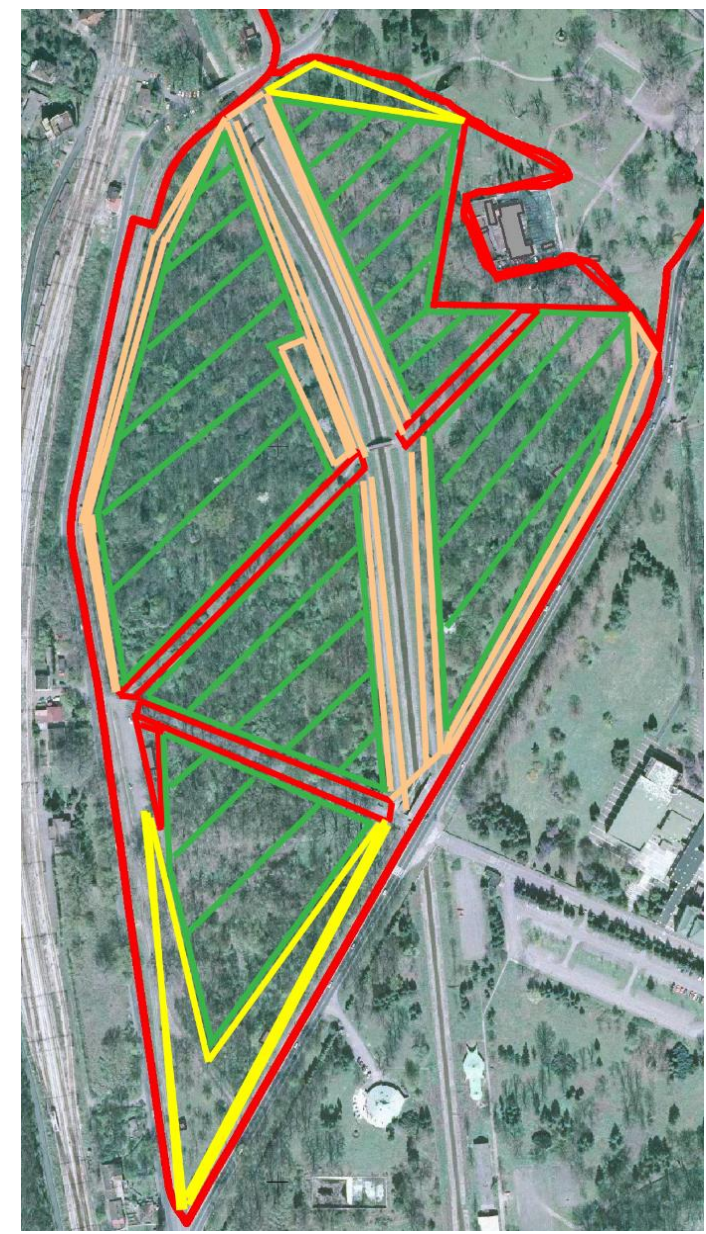

Figure 1: Risk zones in Topčider Forest Park 
Critical trees include completely decayed trees or the trees in different stages of decay along the footpaths, parking lots, tram stop, tram tracks, park furniture or the edge of the forest. Decayed of decaying trees that are found in the interior forest were not designated as risky trees because they do not endanger the safety while contributing to the improvement and conservation of biodiversity of protected species of insects, birds, rodents, etc. which can be found in Topčider Forest Park.

After the rehabilitation, monitoring of the health condition of woody plant species should be focused primarily on the zones marked red and orange.

\section{CONCLUSIONS}

The research distinguished 4 zones of public risk in Topčider Forest Park: the red zone or the zone of very high risk, the orange zone or the zone of high risk, the yellow zone or the zone of medium risk, and the green zone or the zone of low risk.

Due to the risk of branch breakages or uprooting of entire trees, the trees in the critical areas of very high and high risk are proposed to be removed and replaced as soon as possible to ensure the public safety in the forest park.

There are a large number of trees with minor or greater mechanical injuries in the park. Injuries should be managed adequately in order to avoid further penetration and growth of pathogenic fungi, especially the wood-decaying fungi.

Regarding the damage caused by biotic agents, it can be concluded that phytopathogenic fungi are more serious agents of damage than insects and mites. Intense human pressure was found to be the cause of the greatest number of injuries.

Therefore local population should be educated about the importance of green areas in urbanized city areas in order to reduce the instances of direct damage and destruction of trees.

For the establishment of functional green areas in the city core, we need healthy planting stock, properly selected plant species and appropriate measures of tending and protection, such as removal and replacement of decayed trees, substitution of sensitive species with more resistant ones, pruning of decayed branches, tips and other dead parts of trees and coating of the pruned spots, removal and destruction of fruiting bodies of wood-decaying fungi, collection and burning of leaves of the species susceptible to leaf spots and elimination of pupa that give rise to leaf mines, caterpillar litters, galls, etc., preventive treatment with fungicides in the periods critical for infestation, application of fertilizers to physiologically weak species, avoiding the damage to the root, trunk and branches during the construction of infrastructure facilities, irrigation if necessary, etc.

\section{LITERATURE}

Agrios G. N. (2005): Plant Pathology (Fifth Edition). Elsevier Academic Press, Burlington, San Diego, London: 1-922. 
Alexopoulos C. J., Mims C. W., Blackwell M. (1996): Introductory Micology (Fourth Edition). John Wiley and Sons, Inc., New York, Chichester, Brisbane, Toronto, Singapore, $1-868$.

Amrine, J. W. JR., T. A. Stasny, C. H. W. Fletchmann 2003): Revised keys to world genera of Eriophyoidea (Acari: Prostigmata). Indira Publishing House, West Bloomfield, Michigan, USA, p 244.

Baker, E.W., Kono, J., Amrine, J.W. Jr, Delfinado-Baker, M., Stasny, T. (1996): Eriophyoid Mites of the United States. Indira Publishing House. West Bloomfield, Michigan, USA.

Baker, E.W., Tuttle, D.M. (1994): A guide to the spider mites (Tetranychidae) of the United States. Indira Publishing Hous, pp. 347.

Barnett H. L., Hunter B. B. (1998): Illustrated Genera of Imperfect Fungi (Fourth Edition). APS Press, St. Paul, Minesota: 1-218.

Begljarov, G.A. (1981): Key for identification of the predacious mites Phytoseiidae (Parasitiformes, Phytoseiidae) in the fauna of the USSR. Information Bulletin EPS IOBC, 3, str. 141.

Breitenbach J., Kränzlin F. (1986): Champignons de Suisse. Tome 2. Edition Mycologia, CH-6000 Lucerne 9, 1-412.

Černy A. (1989): Parazitické Drevokazné houby. Vydalo ministerstvo lesniho a vodniho hospodárstvi a drevozpracujiciho prumyslu ČSR ve Statnim zemedelskem nakladatelstvi v Praze., 1-100.

Chant D. A. (1959): Phytoseiid mites (Acarina: Phytoseiidae). Part I. Bionomics of seven species in Southeastern England. 1-44 pp.

Davidson R.W., Campbell W.A., Blaisdell J.D. (1938): Differentiation of wood-decaying fungi by their reaction on gallic or tannic acid medium. Journal of Agricultural Research, Vol.57, no.9, Washington, 683-695.

De Moraes G. J., McMurtry J. A., Denmark H. A., Campos C. B. (2004): A revised catalog of the mite family Phytoseiidae. Zootaxa 434: 1-494.

De Moraes, G. J., J. A. McMurtry, H. A. Denmark (1986): A catalog of the family Phytoseiidae. References to taxonomy, synonymy, distribution and habitat. EMBRAPA, Brasilia, Brazil. 353 pp.

Demite, P.R., de Moraes, G.J., McMurtry, J.A., Denmark, H.A., Castilho, R. de C. (2018): Phytoseiidae Database. www.lea.esalq.usp.br/phytoseiidae.

Domes, R., (1998): A new species of the genus Anthocoptes (Phyllocoptinae: Eriophyidae) on Juglans regia L. Acarologia 39 (1): 69-71.

Gajić, M. (1952): O vegetaciji Košutnjaka-Glasnik Šumarskog fakulteta 5, Beograd. 
Gilbertson R. L. (1979): The Genus Phellinus (Aphyllophorales: Hymenochaetaceae) in Western North America. Mycotaxon 9, 51-89, 51-89.

Hagara L., Antonin V., Baier J. (2012): Velký Atlas Hub. Vydalo Ottovo Nakladatelstvi, Praha, 1-432

Johnson, W. T., H. Lyon, (1991): Insects that feed on trees and shrubs. Cornell University Press.

Jung T. (2009): Beech decline in Central Europe driven by the interaction between Phytophthora infections and climatic extremes. Forest Pathology 39: 73-94.

Jung T., Blaschke H., Neumann P. (1996): Isolation, identification and pathogenicity of Phytophthora species from declining oak stands. European Journal of Forest Pathology 26: 253-272.

Jung T., Blaschke H., Oßwald W. (2000): Involvement of soilborne Phytophthora species in Central European oak decline and the effect of site factors on the disease. Plant Pathology 49: 706-718.

Karadžić D. (2010): Šumska fitopatologija. Univerzitet u Beogradu Šumarski fakultet, Beograd, 1-774.

Karadžić D., Milenković I. (2014): Najčešće Inonotus vrste u šumama Srbije i Crne Gore. Šumarstvo br. 3-4, Beograd, 1-18.

Karadžić D., Milenković I. (2015): Prilog poznavanju parazitne gljive Inonotus nidus-pici Pilát uzročnika rak.rana na stablima lišćara. Šumarstvo br. 1-2, 15-29.

Karadžić D., Radulović Z., Milenković I. (2014): Ganoderma vrste u šumama Srbije i Crne Gore. Šumarstvo br. 1-2, Beograd, 1-19

Keifer, H.H. (1938): Eriophyid studies I. BCDA, 27: 181-206.

Keifer, H.H. (1940): Eriophyid studies VIIII. BCDA, 29: 21-46.

Keifer, H.H. (1944): Eriophyid studies XIV BCDA, 33: 18-38.

Keifer, H.H. (1946): A review of the North American economic Eriophyid mites. J. Econ. Entomol. 39: 563-570.

Keifer, H.H. (1952): The Eriophyid mites of California (Acarina: Eriophyidae). Bull Calif Insect Surv 2 (1): 1-123.

Keifer, H.H. (1975): Eriophyoidea Nalepa. Injurious eriophyoid mites. In: Jeppson LR, Keifer HH, Baker EW (eds) Mites injurious to economic plants. University of California Press, Berkeley, pp 327-533.

Keifer, H.H. (1979): Eriophyid studies C-11. ARS-USDA, 24 pp.

Maceljski, M, (1986): Current status of Corythuca ciliata in Europe. Bulletin OEPP/EPPO Bulletin 16: 621-624. 
Maceljski, M. (2002): Poljoprivredna entomologija. Čakovec: Zrinjski, II dopunjeno izdanje.

Malandraki, E., Petanovic, R., Nikolaos, (2004): Description of Two New Species of Eriophyid Mites (Acari: Prostigmata: Eriophyide) Common in Greece and Serbia, Agricultural University of Athens, Laboratory for Agricultural Zoology and Entomology, Iera Odos 75, 11855 Athens, Greece.

Migeon, A., Dorkeld, F. (2018): Spider Mites Web: a comprehensive database for the Tetranychidae. Availabe from http://www.montpellier.inra.fr/CBGP/spmweb.

Mihajlović Lj. (2008): Šumarska entomologija, Univerzitet u BeograduŠumarski fakultet, Beograd

Mihajlović, L. (2007): Metcalfa pruinosa (Say) (Homoptera: Auchenorrhyncha) nova štetna vrsta za entomofaunu Srbije. Glasnik Šumarskog fakulteta, br. 95, str. 127-134.

Milenković I. (2015): Diverzitet vrsta roda Phytophthora i njihova uloga u propadanju stabala u lišćarskim šumama u Srbiji. Univerzitet u Beogradu-Šumarski fakultet, doktorska disertacija, pp. 240.

Mitrofanov, V.I., Strunkova, Z.I., Livshits, I.Z., (1987): Keys to the tetranychid mites (Tetranychidae, Bryobiidae) fauna of the USSR and adjacent countries. SSR, I.o.Z.a.P.E.N.P.T., Dushanbe, Donish: 224 p.

Mladenović, K., Milenković, I., Ćirković-Mitrović, T., Brašanac-Bosanac, LJ. (2016): Evaluation of the Condition of Dendrological Species in Academic Park in Belgrade. Sustainable Forestry, Institute of Forestry, Belgrade, vol.73-74, pp. 19-36.

Murrill W.A. (1903): A Historical Review of the Genera of the Polyporaceae. The Journal of Mycology 9 (2): 87-102.

Murrill W.A., Burlingham G.S., Pennington L.H., Barnhart J.H. (1908): North American Flora, (Agaricales) Polyporaceae-Agaricaceae. The New York Botanical Garden, Volume 9, Part 2: 73-132.

Nalepa, A. (1910): Eriophyiden Gallmilben, Zoologica, 24 (61): 167-293.

Overholts L. O. (1953): The Polyporaceae of the United States, Alaska and Canada. University of Michigan Press. Ann. Arbor, Michigan, 1-466.

Pegler D.N., Waterston J.M. (1968): Descriptopons of Pathogenic Fungi and Bacteria. Set 20, No. 194-197, Commonwealth Mycological Institute, Kew, Surrey, England.

Petanović, R. (1988a): Rhinotergum, a new genus, family Diptilomiopidae (Acari: Eriophyoidea). Acarologia (Paris) 29, 4, 319-323.

Petanović, R. (1988b): Eriofidne grinje u Jugoslaviji, 159 pp. Naučna Knjiga, Beograd.

Petrović-Obradović, O. (2003): Biljne vaši (Aphididae, Homoptera) Srbije. Poljoprivredni fakultet Univerziteta u Beogradu. 
Pritchard, A.E., Baker, E.W. (1955): A revision of the spider mite family Tetranychidae. Memoirs Series, San Francisco, Pacific Coast Entomological Society, 2: 472 p.

Reeves, R.M. (1963): Tetranychidae infesting woody plants in New York State, and a life history study of the elm mite Eotetranychus matthyssei n.sp. Cornell University Agricultural Station Mem.: 99.

Rota, P. (1962): Osservazioni sugli Acari Tetranychidi dannosi alle piante coltivate ed ornamentali in Italia. Bollettino di Zoologia Agraria e di Bachicoltura, 4: 31-136.

Ryvarden L., Johansen I. (1980): A preliminary polypore flora of East Africa. Fungiflora, Oslo-Norway, 1-636

Shi, A., Boczek, J. (2000): Studies on Eriophyoid mites (Acari: Eriophyoidea). XXXV. Bulletin of the polish Academy of Siences, Biological Siences. Vol. 48, No. 3. 241-254.

Smith Meyer M.K.P.S., (1987): African Tetranychidae (Acari: Prostigmata) - with reference to the world genera. Entomology Memoir, Department of Agriculture and Water Supply, Republic of South Africa, 69: 1-175.

Stalpers J.A. (1978): Identification of Wood-inhabiting Aphyllophorales in pure culture. Studies in Mycology, No. 16, Baarn, 1- 248.

Stevanović, V., Jovanović, S, Lakušić, D, Niketić, M. (1995): Diverziitet vaskularne flore Jugoslavije sa pregledom vrsta od međunarodnog značaja. In: Stevanović, V., Vasić, V. (Eds.): Biodiverzitet Jugoslavije sa pregledom vrsta od međunarodnog značaja. Biološki fakultet i Ecolibri, Beograd.

Strouts, R. G., T. G. Winter, (2000): Diagnosis of ill-health in trees. Forestry Comission.

Tanasijević, N., Simova-Tošić, D. (1987): Posebna entomologija. Beograd: Naučna knjiga.

Wagner T., Fischer M. (2002): Proceedings towards a natural classification of the worldwide taxa Phellinus s.l. and Inonotus s.l. and phylogenetic relationships of allied genera. Mycologia 94 (6), 998-1016.

\title{
THE ASSESSMENT OF RISK ZONES IN`TOPČIDER` PARK FOREST ON THE BASIS OF THE HEALTH CONDITION OF WOODY PLANT SPECIES
}

\author{
Katarina MLADENOVIĆ, Zlatan RADULOVIĆ, Vlado ČOKE ̌́A, Đorđe JOVIĆ, \\ Ivan MILENKOVIĆ
}

\section{Summary}

Based on the health status of woody plant species established in 2017, the proximity to roads (tram tracks, the tram stop, footpaths, and parking lots), the available facilities (restaurants, shops, etc.), the frequency of the forest park use, and the age of forest park trees, the zones of risk for the users of Topčider Forest Park were determined.

The research distinguished 4 zones of public risk: the red zone or the zone of very high risk, the orange zone or the zone of high risk, the yellow zone or the zone of medium 
risk, and the green zone or the zone of low risk. The current health condition was assessed and the factors that potentially threaten it were identified using a visual assessment with the following 1 to 5 scale The inspection of the health condition included the detection of mechanical, phytopathological, entomological and acarological damage to the tree crown, trunk and root collar zone, as well as biotic and abiotic damage determination.

The priorities were determined in the monitoring and implementation of rehabilitation measures within the forest park. Due to the risk of branch breakages or uprooting of entire trees, the trees in the critical areas of very high and high risk are proposed to be removed and replaced as soon as possible to ensure the public safety in the forest park. Intense human pressure was found to be the cause of the greatest number of injuries.

For the establishment of functional green areas in the city core, we need healthy planting stock, properly selected plant species and appropriate measures of tending and protection.

\title{
PROCENA RIZIČNIH ZONA PARK ŠUME TOPČIDER NA OSNOVU ZDRAVSTVENE KONDICIJE DRVENASTIH BILJNIH VRSTA
}

\author{
Katarina MLADENOVIĆ, Zlatan RADULOVIĆ, Vlado ČOKEŠA, Đorđe JOVIĆ, \\ Ivan MILENKOVIĆ
}

\section{Izvod}

Na osnovu zdravstvenog stanja drvenastih biljnih vrsta utvrđenog u 2017. godini, blizine saobraćajnica (šina, tramvajske stanice, pešačkih staza, parkinga), prisustva objekata (restoran, prodavnica), frekventnosti korisnika park šume i starosti stabala izvršena je procena rizičnih zona za korisnike park šume Topčider.

Tokom istraživanja izdvojene su 4 rizične zone za korisnike park šume: crvena zona - zona vrlo visokog rizika, narandžasta zona - zona visokog rizika, žuta zona - zona srednjeg rizika, zelena zona - zona malog rizika. Za utvrđivanje zatečenog zdravstvenog stanja i evidentiranje mogućih faktora koji ga ugrožavaju izvršena je vizuelna ocena prema skali od 1 do 5. Pregled zdravstvenog stanja je obuhvatio detekciju mehaničkih, fitopatoloških, entomoloških i akaroloških oštećenja u krošnji, deblu i u zoni korenovog vrata, evidentirana su oštećenja biotičke i abiotičke prirode.

Utvrđen je prioritet nadzora i mera sanacije unutar park šume. Zbog opasnosti od loma grana i delova stabala kao i izvala čitavih stabala, u kritičnim zonama vrlo visokog i visokog rizika predlaženo je uklanjanje i zamena rizičnih stabala u što kraćem vremenskom periodu kako bi se osigurala bezbednost korisnika park šume. Najveći broj oštećenja je direktna posledica antropogenog faktora.

Za podizanje funcionalnih zelenih površina u gradskom jezgru neophodan je zdrav sadni materijal, adekvatan izbor biljnih vrsta kao i primena odgovarajućih mera nege i zaštite 